\title{
Occurrence and sources of selected phenolic endocrine disruptors in Ria de Aveiro, Portugal
}

\author{
Niels Jonkers • Ana Sousa • Susana Galante-Oliveira • \\ Carlos M. Barroso • Hans-Peter E. Kohler • \\ Walter Giger
}

Received: 19 May 2009/Accepted: 21 November 2009/Published online: 17 December 2009

(C) The Author(s) 2009. This article is published with open access at Springerlink.com

\begin{abstract}
Background, aim and scope Ria de Aveiro (Portugal) is a shallow coastal lagoon of high economic and ecological importance. Hardly any data on its chemical pollution by polar organic pollutants are available in literature. This study focused on the presence and sources of a series of phenolic endocrine-disrupting compounds (EDCs) in this area, including parabens, alkylphenolic compounds and bisphenol-A (BPA). A number of possible sources of pollution are present in the area, including the large harbours present in the lagoon, the city of Aveiro and the rivers discharging into the area. A recently constructed submarine wastewater outfall, located a few kilometres from the lagoon inlet has also been suggested as a possible source of pollution to Ria de Aveiro in several publications. The aim of the current field study was to investigate the occurrence and main sources of phenolic endocrine disruptors in Ria de Aveiro.
\end{abstract}

Responsible editor: Ake Bergman

Electronic supplementary material The online version of this article (doi:10.1007/s11356-009-0275-5) contains supplementary material, which is available to authorized users.

\section{N. Jonkers $(\bowtie)$}

IVAM, University of Amsterdam,

Plantage Muidergracht 14,

NL-1018 TV Amsterdam, The Netherlands

e-mail: njonkers@ivam.uva.nl

A. Sousa $\cdot$ S. Galante-Oliveira $\cdot$ C. M. Barroso

CESAM \& Department of Biology, Universidade de Aveiro,

Aveiro, Portugal

H.-P. E. Kohler • W. Giger

Eawag, Swiss Federal Institute for Aquatic Science and Technology,

Dübendorf, Switzerland
Materials and methods An extensive sampling campaign was performed, with surface water and wastewater grab samples taken at over 50 locations, in duplicate on different days. Samples were treated using solid phase extraction and analysed by liquid chromatography tandem mass spectrometry.

Results and discussion Concentrations in lagoon water were generally low: not exceeding $20 \mathrm{ng} / \mathrm{L}$ for most analytes. Levels in river water exceeded those in the lagoon by a factor 3 to 500 (o-phenylphenol $(\mathrm{PhP})$ and nonylphenoxy ethoxy acetic acids (A,PEC), respectively), with concentrations up to $700 \mathrm{ng} / \mathrm{L}$ for BPA and 7,300 $\mathrm{ng} / \mathrm{L}$ for $\mathrm{A}_{9}$ PEC. Samples from the harbours showed EDC levels similar to those in the rest of the lagoon, but in the city of Aveiro, elevated concentrations were observed for alkylphenol ethoxylates ( $\left.\mathrm{A}_{9} \mathrm{PEO}\right), \mathrm{A}_{9} \mathrm{PEC}$, $\mathrm{PhP}$ and BPA. Wastewater effluents showed low levels for parabens, whilst alkylphenolic compounds reached several micrograms per litre. The effluents are discharged into the ocean via a submarine outfall, but as marine water near the outfall showed slightly elevated concentrations only for $\mathrm{A}_{9} \mathrm{PEO}$, it does not seem to be a significant source of these EDCs for the area.

Conclusions All the studied phenolic EDCs were detected in the study area, with high levels found in some of the rivers discharging into the lagoon, and generally low concentrations in the lagoon itself. The main sources for all investigated EDCs were the rivers Caster and Antuã which discharge into the lagoon. The city of Aveiro was identified as a secondary source. As the tidal water exchange volume is much larger than the freshwater input from the rivers, concentrations of phenolic EDCs remained low in the lagoon.

Keywords Endocrine disruptors · Ria de Aveiro · Fate study · Alkylphenols $\cdot$ Parabens 


\section{Background, aim and scope}

Endocrine-disrupting effects in organisms have been shown in a number of field studies over the past 15 years (Jobling et al. 1998; Matthiessen et al. 2002; Vethaak et al. 2005), including several investigations along the Portuguese coast (Barroso et al. 2000; Sousa et al. 2005, 2007; GalanteOliveira et al. 2006). In several of these studies, a relationship between the presence of organotin contaminants and endocrine-disrupting effects could be established. Other endocrine-disrupting compounds (EDCs) have so far received less attention in Portugal, and hardly any published data can be found on the environmental presence of these substances in Portuguese waters (Azevedo et al. 2001; Céspedes et al. 2004; Quirós et al. 2005). In the present study, the environmental occurrence of a combination of some well-known and some newly emerged phenolic EDCs was studied in the Ria de Aveiro lagoon in Portugal. The studied substances are all high production volume chemicals and reach the environment mainly via wastewater. Analytical methods for aqueous samples using solid phase extraction (SPE) and liquid chromatography tandem mass spectrometry (LC-MS/MS) were optimised to be able to determine all these EDCs within one method based on work of Benijts et al. (2004).

The current study includes the non-ionic surfactants nonylphenol ethoxylates $\left(\mathrm{A}_{9} \mathrm{PEO}_{n}\right)$ and their main metabolites nonylphenoxy ethoxy acetic acids $\left(\mathrm{A}_{9} \mathrm{PE}_{n} \mathrm{C}\right)$ and nonylphenol (NP), as well as octylphenol (OP), which is a metabolite of the octylphenol ethoxylate surfactants (Ahel et al. 1994; Jonkers et al. 2001). The study also includes the EDC bisphenol-A (BPA) that is mainly used in the production of polycarbonate plastics and epoxy resins. A large number of studies exist on the environmental behaviour of $\mathrm{A}_{9} \mathrm{PEO}_{n}$ and their metabolites as well as on BPA, and several reviews on this subject are available (Thiele et al. 1997; Staples et al. 1998; Fromme et al. 2002; Ying et al. 2002; Knepper and Berna 2003; Montgomery-Brown and Reinhard 2003; Kang et al. 2006; Giger et al. 2009).

Less well-known EDCs included in this study are the parabens and ortho-phenylphenol. The biocide orthophenylphenol $(\mathrm{PhP})$ is used in diverse products such as glues, concrete additives, leather and as active ingredient in disinfectants. Parabens are a group of chemicals formed by para-hydroxybenzoic acid esters, with alkyl substituents ranging from methyl to butyl or benzyl groups. They are extensively applied as preservatives (usually as mixtures) in a large number of products including cosmetics and toiletries such as shampoos, skin care products and toothpastes (Rastogi et al. 1995; Routledge et al. 1998; Madsen et al. 2001). The parabens most commonly present in consumer products are methylparaben (MeP) and propylparaben (PrP). Both the parabens and ortho-phenylphenol are readily biodegradable under aerobic conditions; however, their high consumption amounts and continuous introduction into the environment may lead to a "pseudopersistent" situation (Madsen et al. 2001).

The objective of the current field study was to investigate the occurrence and main sources of the series of endocrine disruptors mentioned above in Ria de Aveiro in Portugal. With respect to endocrine disruption, this estuarine system is a particularly interesting study area as several studies have shown endocrine-disrupting effects to occur in the area, including high levels of female gastropod molluscs masculinisation and sterility induced by organotin (OT) compounds (Barroso et al. 2000, 2005; GalanteOliveira et al. 2009a, b; Sousa et al. 2005). Apart from data on OTs and heavy metals, hardly any information is available in the literature on the presence of EDCs or other organic microcontaminants in Ria de Aveiro.

Another interesting feature of Ria de Aveiro is the submarine wastewater outfall which was constructed several years ago and discharges all the treated wastewater of the area into the Atlantic Ocean, a few kilometres from the inlet of the estuary. Some literature suggests that a considerable part of this effluent flows back into the lagoon with tidal currents and could therefore be a relevant source of contaminants to the lagoon area (Figueiredo da Silva et al. 2002a). In the current study, the wastewater outfall was considered as one possible main source of EDCs for Ria de Aveiro. Other possible sources include the large harbours present in the lagoon, the city of Aveiro and the rivers discharging into the area.

\section{Materials and methods}

\subsection{Reagents and standards}

The standards of methyl-, ethyl-, propyl- and butylparaben as well as 4-nonylphenol (mixture of isomers) and 2-phenylphenol were obtained from Acros Organics (New Jersey, USA). Benzylparaben, 4-tert-octylphenol and bisphenol-A were purchased from Aldrich (Gillingham, $\mathrm{UK})$. The internal standards $\mathrm{d}_{16}$-BPA and $\mathrm{nNPE}_{2} \mathrm{C}$ were from Cambridge Isotope Laboratories, and ${ }^{13} \mathrm{C}_{6}-\mathrm{NP}$ and ${ }^{13} \mathrm{C}_{6}-\mathrm{A}_{9} \mathrm{PEO}_{1-5}$ were a kind gift from $\mathrm{P}$. Lee Ferguson (SUNY Stony Brook, New York, USA). Solvents (HPLCgrade) were purchased from Scharlau (Sentmenat, Spain), and ammonium acetate was from Merck (Darmstadt, Germany).

\subsection{Study area}

Ria de Aveiro (Fig. 1) is a shallow estuarine system in the northwest of Portugal formed by a complex system of 

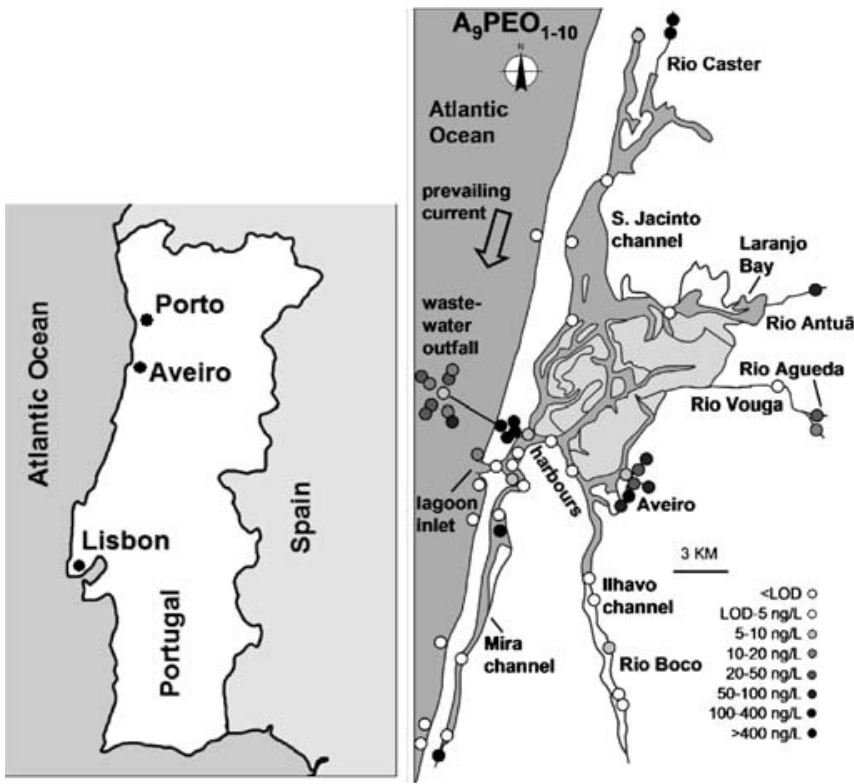

Fig. 1 Top left location of the Aveiro lagoon in Portugal. Top right and below map of the Aveiro lagoon with the main expected sources as well as the sampling locations indicated. Dissolved concentrations of $\mathrm{A}_{9} \mathrm{PEO}_{1-10}, \mathrm{~A}_{9} \mathrm{PEC}$ and $\mathrm{BPA}$ are shown (averages of two sampling

channels and wide intertidal areas (mudflats and salt marshes). The lagoon has a maximum width and length of 10 and $45 \mathrm{~km}$, respectively, and is connected to the sea by an artificial inlet at the west side. The average depth of the lagoon is about $1 \mathrm{~m}$, with a maximum of around $20 \mathrm{~m}$ in the channel near the inlet, and the water column can be considered as vertically homogeneous (Dias and Lopes 2006). The tidal regime is semi-diurnal with a tidal range of around $2 \mathrm{~m}$ at the inlet. Tide generates strong currents in deep and narrow channels, but not in the intertidal areas (Dias et al. 1999, 2000, 2001). The maximum tidal flow is about $4,700 \mathrm{~m}^{3} / \mathrm{s}$. This tidal contribution is much higher than the inputs from the main rivers Vouga and Antuã which, on average, contribute about 50 and $5 \mathrm{~m}^{3} / \mathrm{s}$, respectively (Lopes et al. 2001). Minor rivers flowing into the lagoon are the Rio Caster and Rio Boco.

Ria de Aveiro has three main branches extending from the sea inlet: the Mira, São Jacinto and Ílhavo channels. Seawater intrudes far into the branches, and only deep inside the branches, water salinity decreases below seawater levels in the summer. The whole estuary is heavily influenced by human activities, including tourism (a number of small tourist harbours are present), fishery and aquaculture, transport (large chemical and commercial harbours near the city of Aveiro), agriculture and industry (Jonkers et al. 2009).

The area surrounding the lagoon has a population of approximately 700,000 inhabitants (INE 2008), and a number of industries are present, including a pulp mill, steel and agrochemical industries. The wastewater treatment facilities in the estuary were built relatively recently, and

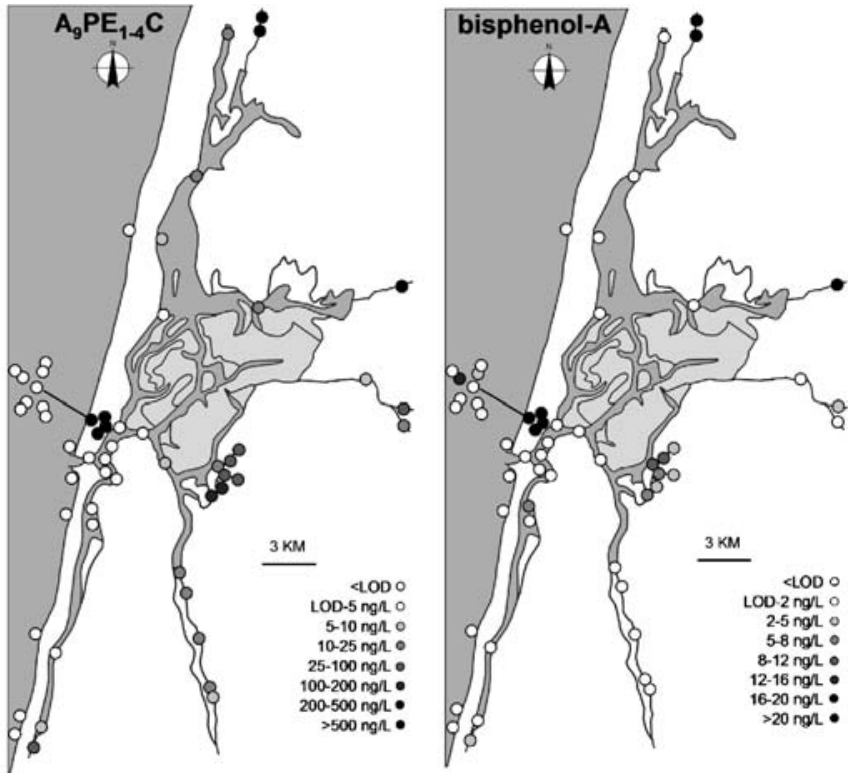

campaigns), with darker circles representing higher concentrations. Dots at the (land side) start of the submarine wastewater outfall pipeline indicate the effluent sample concentrations

until 2000, the effluents were discharged directly into the lagoon. Presently, all legal sources of effluent discharge are directed towards the ocean via a submarine outfall, which discharges domestic (30\%) and industrial (70\%) effluents after secondary treatment into the coastal area at $3.3 \mathrm{~km}$ offshore, $5 \mathrm{~km}$ north of the lagoon inlet (Figueiredo da Silva et al. 2002a). The prevailing inshore water current along the Aveiro coast is to the south. In a study on the Ria de Aveiro wastewater outfall using aerial observations and in situ water sampling, Figueiredo da Silva et al. (2002a, b) observed no offshore transport of the wastewater plume, but most commonly transport in the direction of the lagoon inlet channel. This suggests that impacts of pollutants discharged can be anticipated in nearshore waters and potentially within the estuarine system (Figueiredo da Silva et al. 2002a).

\subsection{Sampling strategy}

The goal of the sampling campaign was to determine the levels of EDC contamination for the whole Ria de Aveiro lagoon, to trace the main sources of phenolic EDCs in the area and to identify possible contamination hot spots. To this end, an extensive sampling campaign was performed in August 2006 in which water grab samples were taken at over 50 locations throughout the study area. One week later, sampling was repeated at the same locations to get an idea of the short-term variability of the system. Locations were selected near possible sources as well as locations where no sources were anticipated and "background levels" 
of EDCs were expected. The following possible sources were considered:

- The submarine wastewater outfall: Marine water samples were taken near the outfall as well as near the inlet of the lagoon where part of the wastewater possibly reenters the lagoon.

- The city of Aveiro: Samples were taken in five of the city's channels and the main entrance canal into the city.

- The large harbours in the vicinity of Aveiro: Two fishing ports, the commercial and the chemical ports were sampled.

- The rivers discharging into the lagoon: The 6 sources of freshwater into the lagoon were sampled, from north to south: Rio Caster, Rio Antuã, Rio Águeda (which flows into Rio Vouga), Rio Vouga, Rio Boco and the far end of the Mira channel.

Diffuse sources of EDCs from (illegally) discharged wastewater and tourism were anticipated as well, but no specific sampling was possible to trace these sources.

In addition, duplicate 24-h wastewater effluent samples were taken from the three wastewater treatment plants (WWTPs) in the study area: WWTP Cacia (ETAR Norte), WWTP Gafanha (ETAR Sul) and wastewater from a large pulp mill. This treated wastewater is not discharged into the estuary, but is led to the submarine wastewater outfall in the ocean. Duplicate samples of the wastewater reaching the outfall were taken as well.

Samples were taken from bridges, piers or from quays using a homemade bottle sampling device on a rope. All samples were taken at low tide. The marine water samples near the submarine wastewater outfall were taken by boat using a Van Dorn sampler and were collected just once.

\subsection{Sample cleanup}

A solid phase extraction method was optimised based on the method of Benijts et al. (2004). After filtration of the water using glass microfiber $(\mathrm{GF} / \mathrm{C})$ filters, the samples were frozen at $-20^{\circ} \mathrm{C}$ until treatment. Before extraction, a mix of internal standards was added, including ${ }^{13} \mathrm{C}_{6}$-NP, ${ }^{13} \mathrm{C}_{6}$-NPEO, $\mathrm{d}_{16}$-BPA and $\mathrm{nNPE}_{2} \mathrm{C}$ (an isomer having a linear alkyl chain and therefore a longer retention time). Extraction sample volumes were $150 \mathrm{~mL}$ for wastewater effluent and $250 \mathrm{~mL}$ for surface waters, with $5 \%$ methanol added to each sample. The SPE cartridges (Oasis HLB $200 \mathrm{mg}$, Waters) were conditioned with hexane, methyl tert-butyl ether (MTBE)/2-propanol (1:1), methanol and nanopure water. Then, the filtered samples (neutral $\mathrm{pH}$ ) were passed through. After loading the cartridges with the sample, $4 \mathrm{~mL}$ of nanopure water was passed through to rinse the cartridge from salts and reduce possible matrix effects during analysis. Then, the cartridges were dried under vacuum. The cartridges were eluted with $3 \mathrm{~mL}$ MTBE/2-propanol (1:1), followed by $3 \mathrm{~mL}$ methanol. Finally, the extract was evaporated under a gentle nitrogen stream and transferred to $250 \mu \mathrm{L}$ methanol/ $\mathrm{H}_{2} \mathrm{O}(1: 1)$.

\subsection{Analysis of phenolic EDCs}

For analysis, a HP1100 liquid chromatography system (Hewlett-Packard, Waldbronn, Germany) coupled to an API4000 triple quadrupole mass spectrometer (Applied Biosystems, Foster City, USA) were used. Chromatographic separation was performed with a Lichrospher 100 RP18ec column (Macherey-Nagel, Dueren, Germany), with nanopure water containing $4 \mathrm{mM}$ ammonium acetate and methanol as mobile phases. An electrospray interface was used in positive ionisation mode for $\mathrm{A}_{9} \mathrm{PEO}_{n}$ and negative mode for all other analytes. Detection was done in multiplereaction monitoring (MRM) mode, with one mass transition for each analyte (see Table 1). LC-MS/MS parameters can be found in the Electronic supplementary material. Quantification was based on external calibration with areas relative to the internal standard areas (at least eight calibration standard solutions, $r^{2}$ was always above 0.97 ). The internal standard used for the parabens, phenylphenol and bisphenol-A was $d_{16}$-bisphenol-A, whilst for the alkylphenols, $\mathrm{A}_{9} \mathrm{PEC}, \mathrm{A}_{9} \mathrm{PEO}_{1,2}$ and $\mathrm{A}_{9} \mathrm{PEO}_{3-10}$, the internal standards ${ }^{13} \mathrm{C}_{6}-\mathrm{NP}, \mathrm{n}-\mathrm{A}_{9} \mathrm{PE}_{2} \mathrm{C},{ }^{13} \mathrm{C}_{6}-\mathrm{A}_{9} \mathrm{PEO}_{2}$ and ${ }^{13} \mathrm{C}_{6}-\mathrm{A}_{9} \mathrm{PEO}_{3}$ were used, respectively. The concentrations determined were corrected for average blank value and relative recovery.

\subsection{Quality control}

Along with each extraction round of 12 samples, a blank and a spiked sample (at levels from 150 to $1,000 \mathrm{ng} / \mathrm{L}$ ) were processed. From these samples, relative recoveries were calculated. Limits of quantification were calculated as 10 times the standard deviation of the blank values, or for analytes where no significant blank signals were present, as signal-to-noise ratios of 10 .

\section{Results and discussion}

\subsection{Quality control}

Eight field samples (from sea, river, lagoon and wastewater) were spiked to check the recovery of the extraction and possible interferences or matrix effects in the LC-MS/MS analysis. Recoveries were close to $100 \%$ (see Table 1). For 
some analytes, the average recoveries were above $100 \%$, which indicates that matrix effects either cause an analyte signal enhancement (slightly) higher than for the internal standard or an internal standard signal suppression stronger than for the analyte. Environmental samples were corrected for recovery percentage.

Blank levels were relatively high for NP, leading to a higher limit of quantification (LOQ) for this analyte, as shown in Table 1. Blank levels (those of NP) were always below those of the environmental samples. The average of the blank levels was subtracted from the samples.

\subsection{Salinity}

At most of the locations sampled, salinities around 38 psu were measured. Clearly, the influence of ocean water is much larger than that of freshwater entering the study area. Only deep into the Mira Channel (southwestern channel) and in the rivers were lower salinities measured. In almost all cases, the highest concentrations of phenolic EDCs were found at salinity 0 psu. However, with the current data set, it is not meaningful to evaluate the correlations between salinity and EDC concentrations in detail as the data are strongly clustered around salinity 38 and 0 psu.

\subsection{Occurrence of phenolic EDCs}

When comparing the phenolic EDC concentrations of the two samples from each location (taken 1 week apart), an overall median concentration difference over all analytes of a factor of 1.9 was found. This indicates that concentrations were reasonably constant during the sampling period and that the grab samples give a representative indication of contaminant levels in the study area.

The dissolved concentrations of phenolic EDCs are presented in Table 2. Median and average concentrations for the different types of water sample are given, as well as minimum and maximum concentrations found. In Fig. 1, the spatial distribution of the concentrations for $\mathrm{A}_{9} \mathrm{PE}_{1-4} \mathrm{C}$, $\mathrm{A}_{9} \mathrm{PEO}_{1-10}$ and BPA are shown.

The wastewater effluents were dominated by the alkylphenolic compounds, with the oxidised metabolites $\left(\mathrm{A}_{9} \mathrm{PE}_{1-4} \mathrm{C}\right)$ present at highest concentrations. Median concentrations were $3,260,990$ and $1,500 \mathrm{ng} / \mathrm{L}$ for total $\mathrm{A}_{9} \mathrm{PE}_{1-4} \mathrm{C}, \mathrm{A}_{9} \mathrm{PEO}_{1-10}$ and $\mathrm{NP}$, respectively. Effluent concentrations of BPA and $\mathrm{PhP}$ were generally above $100 \mathrm{ng} / \mathrm{L}$, whilst $\mathrm{OP}$ and total paraben concentrations were lower, with medians of 17 and $27 \mathrm{ng} / \mathrm{L}$, respectively. The paraben species with highest concentrations were $\mathrm{MeP}$ and PrP, which reflects the composition of paraben mixtures in common consumer products (Rastogi et al. 1995). Clearly, the secondary treatment in the WWTPs does not fully remove the phenolic EDCs present in the wastewater.

For all analytes, the highest concentrations in surface water were found in the river samples of Rio Caster, followed by Rio Antuã. Again, alkylphenolic compounds showed the highest levels, with maximum concentrations of $8,200,1,540$ and $233 \mathrm{ng} / \mathrm{L}$ for total $\mathrm{A}_{9} \mathrm{PE}_{1-4} \mathrm{C}, \mathrm{A}_{9} \mathrm{PEO}_{1-10}$ and NP, respectively. For $\mathrm{A}_{9} \mathrm{PEO}$ and $\mathrm{A}_{9} \mathrm{PEC}$, the concentration ranges in the Rio Caster are similar to those found in the wastewater effluents. The average concentration ratio of $\mathrm{A}_{9} \mathrm{PEC} / \mathrm{A}_{9} \mathrm{PEO}$ of around 8 shows that in these rivers, the oxidative hydrolytic degradation route prevails over the non-oxidative route for $\mathrm{A}_{9} \mathrm{PEO}$ (Jonkers et al. 2001). BPA levels were high in Rio Caster as well, with a maximum of $683 \mathrm{ng} / \mathrm{L}$. The other rivers (Rio Vouga, Águeda and Boco) showed considerably lower levels, which were only slightly higher than in the saline waters.

Samples from the Aveiro city channels showed concentrations higher than in the lagoon for alkylphenolic compounds and BPA. Maximum levels in the channels for total $\mathrm{A}_{9} \mathrm{PE}_{1-4} \mathrm{C}, \mathrm{A}_{9} \mathrm{PEO}_{1-10}$, NP and BPA were 251, 266, 74 and $18 \mathrm{ng} / \mathrm{L}$, respectively. For both the city and river samples, the $\mathrm{A}_{9} \mathrm{PEO}$ oligomers present at highest abundance were of medium chain length $\left(\mathrm{A}_{9} \mathrm{PEO}_{3-7}\right)$. This indicates that inputs of $\mathrm{A}_{9} \mathrm{PEO}$ occurred recently as in surface water, these surfactants are easily biodegraded into the metabolites $\mathrm{A}_{9} \mathrm{PEO}_{1-2}$ or $\mathrm{A}_{9} \mathrm{PEC}$ (Jonkers et al. 2001).

Lagoon waters showed generally low levels of phenolic EDCs, with concentrations up to several tens of nanograms per litre. Samples taken in the harbours showed concentrations similar to those found elsewhere in the lagoon for all phenolic EDCs.

Levels in the coastal zone and lagoon were comparable for all compounds. For $\mathrm{A}_{9} \mathrm{PEO}_{1-10}$ only, concentrations were slightly elevated near the marine outfall compared to the other coastal locations.

\subsection{Sources of EDCs}

From a comparison of EDC concentrations in different sample types, the main sources of phenolic EDCs to the Ria de Aveiro can be derived.

For the alkylphenolic compounds, concentrations were considerably higher in the rivers (especially Rio Caster and Rio Antuã) and city channels than in the lagoon or sea samples. Therefore, these are considered as the main sources of $\mathrm{A}_{9} \mathrm{PEO}$ and $\mathrm{A}_{9} \mathrm{PEC}$ to the lagoon. It is difficult to compare the contribution of the river and city sources quantitatively as the city channels are flushed with relatively clean seawater during each high tide and are therefore likely to vary strongly (with the current low tide samples representing a maximum concentration), whilst the concentrations in the river are not influenced by tidal movement. 
Table 1 Mass transitions monitored for the investigated analytes

\begin{tabular}{|c|c|c|c|c|c|}
\hline Analyte & MW & MRM transition & Retention time (min) & Relative recovery $(\%)(n=8)$ & LOQ (ng/L) \\
\hline Methylparaben & 152.2 & $151.1 \rightarrow 92.0$ & 9.3 & 111 & 2.0 \\
\hline Ethylparaben & 166.2 & $164.9 \rightarrow 92.0$ & 11.6 & 107 & 0.3 \\
\hline Propylparaben & 180.2 & $178.9 \rightarrow 92.0$ & 13.8 & 113 & 0.5 \\
\hline Butylparaben & 194.2 & $193.1 \rightarrow 92.0$ & 16.3 & 121 & 0.2 \\
\hline Benzylparaben & 228.3 & $227.2 \rightarrow 92.0$ & 16.4 & 118 & 0.2 \\
\hline Bisphenol-A & 228.3 & $227.2 \rightarrow 211.8$ & 14.1 & 100 & 1.0 \\
\hline Phenylphenol & 170.2 & $168.9 \rightarrow 114.9$ & 15.7 & 91 & 2.0 \\
\hline Octylphenol & 206.3 & $205.2 \rightarrow 132.8$ & 24.2 & 124 & 1.0 \\
\hline Nonylphenol & 220.4 & $219.1 \rightarrow 133.0$ & 26.3 & 121 & 29 \\
\hline \multirow[t]{4}{*}{$\mathrm{A}_{9} \mathrm{PE}_{1-4} \mathrm{C}$} & 278.3 & $277.2 \rightarrow 218.9$ & 17.2 & 123 & 0.6 \\
\hline & 322.3 & $321.2 \rightarrow 218.9$ & 18.3 & & 0.6 \\
\hline & 366.3 & $365.2 \rightarrow 218.9$ & 18.7 & & 0.6 \\
\hline & 410.3 & $409.2 \rightarrow 218.9$ & 18.9 & & 0.6 \\
\hline $\mathrm{d}_{16}-\mathrm{BPA}$ & 244.3 & $241.0 \rightarrow 223.2$ & 14.1 & - & - \\
\hline $\mathrm{n}-\mathrm{A}_{9} \mathrm{PE}_{2} \mathrm{C}$ & 322.3 & $321.2 \rightarrow 218.9$ & 20.7 & - & - \\
\hline${ }^{13} \mathrm{C}_{6}-\mathrm{NP}$ & 226.4 & $225.3 \rightarrow 139.1$ & 26.3 & - & - \\
\hline $\mathrm{A}_{9} \mathrm{PEO}_{1}$ & 264.4 & $282.2 \rightarrow 127.1$ & 6.9 & 95 & 7.0 \\
\hline $\mathrm{A}_{9} \mathrm{PEO}_{2}$ & 308.5 & $326.2 \rightarrow 183.2$ & 7.1 & 96 & 0.7 \\
\hline \multirow[t]{8}{*}{$\mathrm{A}_{9} \mathrm{PEO}_{3-10}$} & 352.5 & $370.3 \rightarrow 227.1$ & 7.2 & 117 & 0.9 \\
\hline & 396.5 & $414.4 \rightarrow 271.1$ & & & \\
\hline & 440.5 & $458.4 \rightarrow 315.2$ & & & \\
\hline & 484.5 & $502.4 \rightarrow 359.2$ & & & \\
\hline & 528.6 & $546.5 \rightarrow 291.2$ & & & \\
\hline & 572.6 & $590.5 \rightarrow 291.2$ & & & \\
\hline & 616.6 & $634.6 \rightarrow 291.2$ & & & \\
\hline & 660.6 & $678.6 \rightarrow 291.2$ & & & \\
\hline${ }^{13} \mathrm{C}_{6}-\mathrm{NPEO}_{2}$ & 314.5 & $332.4 \rightarrow 189.2$ & 7.1 & - & - \\
\hline${ }^{13} \mathrm{C}_{6}-\mathrm{NPEO}_{3}$ & 358.5 & $376.3 \rightarrow 233.2$ & 7.2 & - & - \\
\hline
\end{tabular}

Parent ions are ammonium adducts for $\mathrm{A}_{9} \mathrm{PEO}_{1-10}$ and deprotonated molecules for all other analytes

The strong concentration differences for the different rivers (averages of 17 and $817 \mathrm{ng} / \mathrm{L}$ for $\mathrm{A}_{9} \mathrm{PEO}_{1-10}$ and 17 and $6530 \mathrm{ng} / \mathrm{L}$ for $\mathrm{A}_{9} \mathrm{PE}_{1-4} \mathrm{C}$ in the Rio Vouga and Rio Caster, respectively) can be partially explained by the differences in population densities in the river catchments, which is around 110 inhabitants per square kilometre for the Rio Vouga and 470 inhabitants per square kilometre for the Rio Caster and Antuã (Figueiredo da Silva et al. 2002b). An additional explanation for the concentration differences is the stronger dilution capacity in the Rio Vouga as the water flows of the rivers are $50 \mathrm{~m}^{3} / \mathrm{s}$ for Rio Vouga, $5 \mathrm{~m}^{3} / \mathrm{s}$ for Rio Antuã and $<1 \mathrm{~m}^{3} / \mathrm{s}$ for Rio Caster and Rio Boco (yearly averages; Lopes et al. 2005). In the winter season, both river water flows and the fraction of river water in the lagoon increase. Differences in water flows as large as approximately $3 \mathrm{~m}^{3} / \mathrm{s}$ in September compared to approximately $150 \mathrm{~m}^{3} / \mathrm{s}$ in May have been reported for the Rio Vouga (Figueiredo da Silva et al. 2002b). Salinity at the far end of the São Jacinto channels decreases to around 15 psu in the northern half of the channel (Lopes et al. 2005). Therefore, in the winter season, concentrations of EDCs originating from the rivers may be higher at the far ends of the lagoon channels. However, the higher river water flows do not necessarily mean higher loads of EDCs (as the river water may be diluted), and therefore, seasonal fluctuations may play only a minor role.

The high concentrations of $\mathrm{A}_{9} \mathrm{PEO}$ and $\mathrm{A}_{9} \mathrm{PEC}$ in wastewater did not lead to significantly increased concentrations in seawater near the submarine outfall for most of the analysed oligomers. Only for $\mathrm{A}_{9} \mathrm{PEO}_{3-7}$ were slightly increased concentrations found near the outfall. However, since the seawater samples were taken at $\sim 1-\mathrm{m}$ depth, it cannot be excluded that a deeper lying current with more polluted water exists.

For NP, the median concentrations in all surface water types were similar, which illustrates the ubiquitous nature 


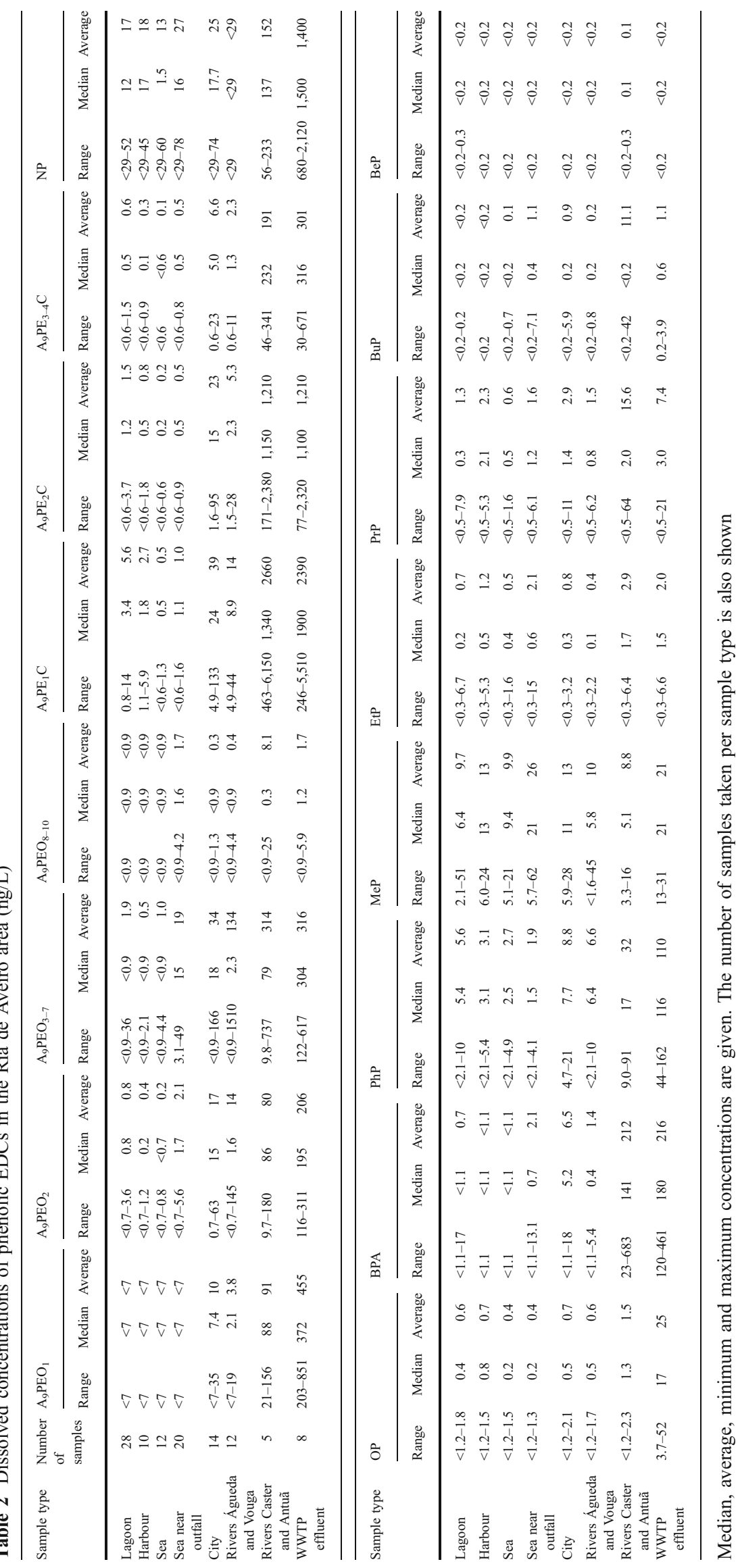


of this substance. Maximum NP concentrations were found in the Rio Caster and Rio Antuã, and therefore, these two rivers are considered as the main source of NP to the lagoon. However, even in those rivers, the Environmental Quality Standard $(\mathrm{EQS}=0.3 \mu \mathrm{g} / \mathrm{L})$ set by the European Water Framework Directive was not exceeded (European Parliament and Council 2007). Concentrations of OP were extremely low in all surface waters, and therefore, no source could be indicated for this substance.

For BPA and PhP, the main sources again seem to be the Caster and Antuã river and, to a lower extent, the city of Aveiro. Although BPA and PhP were present in the wastewater, this did not lead to significantly elevated concentrations near the submarine outlet.

For MeP, concentrations are similar in all sample types, and no obvious sources can be distinguished. For the other parabens, concentrations in almost all surface water samples are very low, which is not surprising as these compounds are readily biodegradable (Madsen et al. 2001). The only elevated concentrations found are in the Rio Caster (up to $64 \mathrm{ng} / \mathrm{L}$ for $\mathrm{PrP}$ ), which suggests a continuous discharge of untreated (or ineffectively treated) wastewater into this river.

The harbours in the lagoon, which have received relatively much attention in the past due to the presence of alkyltin EDCs (used as antifouling agents), do not seem to be significant sources of the EDCs investigated in this study.

As concentrations throughout the whole lagoon area remained low, diffuse sources from illegal discharges seem to be not very relevant. Only the elevated concentrations of some EDCs (alkylphenolic compounds and BPA) in the channels of Aveiro suggest some minor diffuse sources in the city. All of the city's sewage system is connected to the submarine wastewater outfall.

\subsection{Comparison to literature}

For the Ria de Aveiro, not many data on micropollutant concentrations are available in literature. In a study on nutrient inputs into the lagoon, the rivers Antuã and Caster were found to contain higher concentrations of ammonium, nitrate and total phosphorus than the Vouga River, which is in agreement with our results for EDC concentrations (Figueiredo da Silva et al. 2002b). In that study, a considerable increase in nutrient loads into the lagoon from the ocean was expected, originating from the submarine outlet when it would come into use (in 2005). This expectation is not sustained by our current findings of low EDC concentrations near the outlet.

In the east of the lagoon, an area called Laranjo Bay is known to be polluted (a.o. by heavy metals) due to industrial activities (Lopes et al. 2001, 2005). The phenolic
EDCs did not show elevated concentrations in this area, which can be explained by the fact that for several of the large industries in the area, the wastewater is no longer discharged into the lagoon but into the ocean via the submarine outfall.

In a study by Quirós et al. (2005), estrogenic activity and the occurrence of several EDCs in several Portuguese rivers were assessed using a recombinant yeast assay and LC-MS analysis. In the Ria de Aveiro, samples were taken in the Vouga River near the point where it enters the lagoon. Whilst in that study the Ria de Aveiro system was one of the sites showing low estrogenic activity compared to samples of other Portuguese sites, the average concentrations of the measured EDCs $\left(\mathrm{A}_{9} \mathrm{PEO}_{1,2}, \mathrm{NP}, \mathrm{OP}\right.$ and $\left.\mathrm{BPA}\right)$ were a factor 10 higher than in the current samples from the Vouga River or the lagoon. At the time of sampling (20012002), the regional sewage collection system (connected to the marine outlet) was not yet fully operational (Figueiredo da Silva et al. 2002b). Since that time the number of inhabitants connected to the system has almost tripled (Figueiredo da Silva et al. 2002b), which may explain the considerably lower river concentrations found in the present study.

Compared to data on the occurrence of phenolic EDCs in coastal areas of other South European countries, the concentrations from the current study are relatively low (Kveštak and Ahel 1994; Petrovic et al. 2002; Pojana et al. 2007; Arditsoglou and Voutsa 2008). Petrovic et al. (2002) found aqueous concentrations of $\mathrm{A}_{9} \mathrm{PEO}$ along the Spanish coast above $1 \mu \mathrm{g} / \mathrm{L}$ on several locations which were impacted by wastewater discharges, with a maximum of $11 \mu \mathrm{g} / \mathrm{L}$. A study in a Croatian lagoon showed maximum concentrations of 1.2 and $1.3 \mu \mathrm{g} / \mathrm{L}$ for $\mathrm{NP}$ and $\mathrm{A}_{9} \mathrm{PEO}_{2}$, respectively, which is more than an order of magnitude higher than in the current study (Kveštak and Ahel 1994). Lower levels similar to those in the present study were found recently in the lagoon of Venice (Italy) by Pojana et al. (2007), with concentrations in the low nanogram per litre range for $\mathrm{BPA}, \mathrm{NP}$ and $\mathrm{A}_{9} \mathrm{PE}_{1} \mathrm{C}$. An explanation for the relatively low concentrations found in the current study may be the effective dilution of the wastewater discharged by the submarine outfall and the reduction in emissions after the recent EU restrictions in use of $\mathrm{A}_{9} \mathrm{PEO}$ (Cox and Drys 2003).

Concentrations in the present study found for alkylphenolic compounds and BPA in the Rio Caster are comparable to levels generally found in Northern European rivers (Heemken et al. 2001; Jonkers et al. 2003; Voutsa et al. 2006) and lower than some heavily polluted rivers such as near Barcelona (Spain, Céspedes et al. 2005), Porto and Lisbon (Portugal; Quirós et al. 2005).

The few literature data available on the environmental occurrence of parabens show low concentrations similar to 
those of the present study. In river water from Belgium, maximum paraben concentrations of $0.085 \mu \mathrm{g} / \mathrm{L}$ were found (Benijts et al. 2004). In Canadian municipal wastewater, individual paraben concentrations were observed up to 2.4 and $0.04 \mu \mathrm{g} / \mathrm{L}$ for influent and effluent, respectively, with methyl- and propylparaben present at the highest levels (Lee et al. 2005). A study on a Spanish wastewater treatment plant showed maximum paraben concentrations of $2.9 \mu \mathrm{g} / \mathrm{L}$ in influent and $0.06 \mu \mathrm{g} / \mathrm{L}$ in effluent (Canosa et al. 2006).

\section{Conclusions}

All phenolic EDCs investigated were detected in water from the Ria de Aveiro lagoon system, with high levels found in some of the rivers discharging into the lagoon and generally low concentrations in the lagoon itself. The main EDC sources found were the rivers Caster and Antuã, whilst the city of Aveiro was found to be a minor source (for $\mathrm{A}_{9} \mathrm{PEO}, \mathrm{A}_{9} \mathrm{PEC}$ and $\mathrm{BPA}$ ). In contrast to suggestions in some recent scientific publications, the submarine wastewater outfall does not seem to be an important source of phenolic EDCs to this estuarine system as near the outfall, slightly elevated levels were found only for $\mathrm{A}_{9} \mathrm{PEO}$.

Acknowledgements Isabel Quintaneiro and Margarida Esteves from the SIMRIA wastewater authority are kindly acknowledged for providing wastewater samples. We thank René Schönenberger and Josef Asmin for their assistance in the laboratory and Marc Suter for scientific advice. This work was financed by the Swiss National Science Foundation (National Research Program NRP50, Project PHENCON).

Open Access This article is distributed under the terms of the Creative Commons Attribution Noncommercial License which permits any noncommercial use, distribution, and reproduction in any medium, provided the original author(s) and source are credited.

\section{References}

Ahel M, Giger W, Schaffner C (1994) Behavior of alkylphenol polyethoxylate surfactants in the aquatic environment.1. Occurrence and transformation in sewage-treatment. Water Res 28:1131-1142

Arditsoglou A, Voutsa D (2008) Determination of phenolic and steroid endocrine disrupting compounds in environmental matrices. Environ Sci Pollut Res 15:228-236

Azevedo DDA, Lacorte S, Viana P, Barceló D (2001) Occurrence of nonylphenol and bisphenol-A in surface waters from Portugal. J Brazil Chem Soc 12:532-537

Barroso CM, Moreira MH, Gibbs PE (2000) Comparison of imposex and intersex development in four prosobranch species for TBT monitoring of a Southern European estuarine system (Ria de Aveiro, NW Portugal). Marine Ecol Prog Ser 201:221-232

Barroso CM, Reis-Henriques MA, Ferreira M, Gibbs PE, Moreira MH (2005) Organotin contamination, imposex and androgen/estrogen ratios in natural populations of Nassarius reticulatus along a ship density gradient. Appl Organometallic Chem 19:1141-1148

Benijts T, Lambert W, De Leenheer A (2004) Analysis of multiple endocrine disruptors in environmental waters via wide-spectrum solid-phase extraction and dual-polarity ionization LC-ion trapMS/MS. Anal Chem 76:704-711

Canosa P, Rodriguez I, Rubi E, Bollain MH, Cela R (2006) Optimisation of a solid-phase microextraction method for the determination of parabens in water samples at the low ng per litre level. J Chromatogr A 1124:3-10

Céspedes R, Petrovic M, Raldúa D, Saura U, Piña B, Lacorte S, Viana P, Barceló D (2004) Integrated procedure for determination of endocrine-disrupting activity in surface waters and sediments by use of the biological technique recombinant yeast assay and chemical analysis by LC-ESI-MS. Anal Bioanal Chem 378:697708

Céspedes R, Lacorte S, Raldúa D, Ginebreda A, Barceló D, Piña B (2005) Distribution of endocrine disruptors in the Llobregat River basin (Catalonia, NE Spain). Chemosphere 61:1710 1719

Cox P, Drys G (2003) Directive 2003/53/EC of the European Parliament and of the council. Official Journal of the European Communities, 17.7.2003, document L178

Dias JM, Lopes JF (2006) Implementation and assessment of hydrodynamic, salt and heat transport models: the case of Ria de Aveiro lagoon (Portugal). Environ Model Softw 21:1-15

Dias JM, Lopes J, Dekeyser I (1999) Hydrological characterisation of Ria de Aveiro, Portugal, in early summer. Oceanol Acta 22:473485

Dias JM, Lopes JF, Dekeyser I (2000) Tidal propagation in Ria de Aveiro Lagoon, Portugal. Phys Chem Earth, Part B Hydrol Oceans Atmos 25:369-374

Dias JM, Lopes JF, Dekeyser I (2001) Lagrangian transport of particles in Ria de Aveiro Lagoon, Portugal. Phys Chem Earth, Part B Hydrol Oceans Atmos 26:721-727

European Parliament and Council (2007) Draft Priority Substances directive (Water Framework Directive): Common position adopted by the Council with a view to the adoption of a Directive of the European Parliament and of the Council on environmental quality standards in the field of water policy and amending Directives 82/176/EEC, 83/513/EEC, 84/156/EEC, 84/491/EEC, 86/280/EEC and 2000/60/EC

Figueiredo da Silva J, Duck RW, Hopkins TS, Anderson JM (2002a) Nearshore circulation revealed by wastewater discharge from a submarine outfall, Aveiro Coast, Portugal. Hydrol Earth Syst Sci 6:983-989

Figueiredo da Silva J, Duck RW, Hopkins TS, Rodrigues M (2002b) Evaluation of the nutrient inputs to a coastal lagoon: the case of the Ria de Aveiro, Portugal. Hydrobiologia 475 (476):379-385

Fromme H, Kuchler T, Otto T, Pilz K, Muller J, Wenzel A (2002) Occurrence of phthalates and bisphenol $\mathrm{A}$ and $\mathrm{F}$ in the environment. Water Res 36:1429-1438

Galante-Oliveira S, Langston WJ, Burt G, Pereira ME, Barroso CM (2006) Imposex and organotin body burden in the dog-whelk (Nucella lapillus, L.) along the Portuguese coast. Appl Organometallic Chem 20:1-4

Galante-Oliveira S, Oliveira I, Jonkers N, Langston WJ, Pacheco M, Barroso CM (2009a) Imposex levels and tributyltin (TBT) pollution in Ria de Aveiro (NW, Portugal) between 1997 and 2007: evaluation of legislation effectiveness. J Environ Monit 11:1405-1411

Galante-Oliveira S, Oliveira I, Pacheco M, Barroso CM (2009b) Hydrobia ulvae imposex levels at Ria de Aveiro (NW Portugal) between 1998 and 2007: a counter-current bioindicator? J Environ Monit. doi:10.1039/b908597a 
Giger W, Gabriel FLP, Jonkers N, Wettstein FE, Kohler HPE (2009) Environmental fate of phenolic endocrine disruptors: field and laboratory studies. Phil Trans Soc A 367:3941-3963

Heemken OP, Reincke H, Stachel B, Theobald N (2001) The occurrence of xenoestrogens in the Elbe River and the North Sea. Chemosphere 45:245-259

Instituto Nacional de Estatística-INE (2008) Estimativas provisórias de população residente, 2007 Portugal, NUTS II, NUTS III e municípios. Lisboa, Portugal. ISSN 1645-8389

Jobling S, Nolan M, Tyler CR, Brighty G, Sumpter JP (1998) Widespread sexual disruption in wild fish. Environ Sci Technol 32:2498-2506

Jonkers N, Knepper TP, De Voogt P (2001) Aerobic biodegradation studies of nonylphenol ethoxylates in river water using liquid chromatography-electrospray tandem mass spectrometry. Environ Sci Technol 35:335-340

Jonkers N, Laane RWPM, De Voogt P (2003) Fate of nonylphenol ethoxylates and their metabolites in two Dutch estuaries: evidence of biodegradation in the field. Environ Sci Technol 37:321-327

Jonkers N, Kohler HPE, Dammshäuser A, Giger W (2009) Mass flows of endocrine disruptors in the Glatt River during varying weather conditions. Environ Pollut 157:714-723

Kang JH, Kondo F, Katayama Y (2006) Human exposure to bisphenol A. Toxicology 226:79-89

Knepper TP, Berna JL (2003) Surfactants: properties, production, and environmental aspects. In: Knepper TP, Barceló D, De Voogt P (eds) Analysis and fate of surfactants in the aquatic environment. Elsevier, Amsterdam

Kveštak R, Ahel M (1994) Occurrence of toxic metabolites from nonionic surfactants in the Krka river estuary. Ecotox Environ Saf 28:25-34

Lee HB, Peart TE, Svoboda ML (2005) Determination of endocrine-disrupting phenols, acidic pharmaceuticals, and personal-care products in sewage by solid-phase extraction and gas chromatography-mass spectrometry. J Chromatogr A 1094:122-129

Lopes JF, Dias JM, Dekeyser I (2001) Influence of tides and river inputs on suspended sediment transport in the Ria de Aveiro lagoon, Portugal. Phys Chem Earth, Part B Hydrol Oceans Atmos 26:729-734

Lopes JF, Dias JM, Cardoso AC, Silva CIV (2005) The water quality of the Ria de Aveiro lagoon, Portugal: from the observations to the implementation of a numerical model. Mar Environ Res 60:594-628

Madsen T, Buchardt Boyd H, Nylén D, Rathmann Pedersen A, Petersen GI, Simonsen F (2001) Environmental and health assessment of substances in household detergents and cosmetic detergent products. Danish Environmental Protection Agency report no.615, Copenhagen
Matthiessen P, Allen Y, Bamber S, Craft J, Hurst M, Hutchinson T, Feist S, Katsiadaki I, Kirby M, Robinson C, Scott S, Thain J, Thomas $\mathrm{K}$ (2002) The impact of oestrogenic and androgenic contamination on marine organisms in the United Kingdom - summary of the EDMAR programme. Mar Environ Res 54:645-649

Montgomery-Brown J, Reinhard M (2003) Occurrence and behavior of alkylphenol polyethoxylates in the environment. Environ Eng Sci 20:471-486

Petrovic M, Fernández-Alba AR, Borrull F, Marce RM, GonzálezMazo E, Barceló D (2002) Occurrence and distribution of nonionic surfactants, their degradation products, and linear alkylbenzene sulfonates in coastal waters and sediments in Spain. Environ Toxicol Chem 21:37-46

Pojana G, Gomiero A, Jonkers N, Marcomini A (2007) Natural and synthetic endocrine disrupting compounds (EDCs) in water, sediment and biota of a coastal lagoon. Environ Int 33:929-936

Quirós L, Céspedes R, Lacorte S, Viana P, Raldúa D, Barceló D, Piña B (2005) Detection and evaluation of endocrine-disruption activity in water samples from Portuguese rivers. Environ Toxicol Chem 24:389-395

Rastogi SC, Schouten A, Dekruijf N, Weijland JW (1995) Contents of methylparaben, ethylparaben, propylparaben, butylparaben and benzylparaben in cosmetic products. Contact Dermatitis 32:28-30

Routledge EJ, Parker J, Odum J, Ashby J, Sumpter JP (1998) Some alkyl hydroxy benzoate preservatives (parabens) are estrogenic. Toxicol Appl Pharmacol 153:12-19

Sousa A, Mendo S, Barroso CM (2005) Imposex and organotin contamination in Nassarius reticulatus (L.) along the Portuguese coast. Appl Organometallic Chem 19:315-323

Sousa A, Matsudaira C, Takahashi S, Tanabe S, Barroso C (2007) Integrative assessment of organotin contamination in a southern European estuarine system (Ria de Aveiro, NW Portugal): tracking temporal trends in order to evaluate the effectiveness of the EU ban. Mar Poll Bull 54:1645-1653

Staples CA, Dorn PB, Klecka GM, O'Block ST, Harris LR (1998) A review of the environmental fate, effects, and exposures of bisphenol A. Chemosphere 36:2149-2173

Thiele B, Günther K, Schwuger M (1997) Alkylphenol ethoxylates: trace analysis and environmental behavior. Chem Rev 97:3247-3272

Vethaak AD, Lahr J, Schrap SM, Belfroid AC, Rijs GBJ, Gerritsen A, de Boer J, Bulder AS, Grinwis GCM, Kuiper RV, Legler J, Murk TAJ, Peijnenburg W, Verhaar HJM, de Voogt P (2005) An integrated assessment of estrogenic contamination and biological effects in the aquatic environment of The Netherlands. Chemosphere 59:511-524

Voutsa D, Hartmann P, Schaffner C, Giger W (2006) Benzotriazoles, alkylphenols and bisphenol a in municipal wastewaters and in the Glatt River, Switzerland. Environ Sci Pollut Res 13:333-341

Ying GG, Williams B, Kookana R (2002) Environmental fate of alkylphenols and alkylphenol ethoxylates - a review. Environ Int 28:215-226 